\title{
Detection of Human Papillomavirus Type 52b in Cervical Dysplastic Tissue
}

\author{
Nobuo Yaegashi, Hajime Yajima, ${ }^{*}$ Ryo Konno, Kazuo \\ Shikano, Shinji Sato and Akira Yajima
}

Department of Obstetrics and Gynecology, Tohoku University School of Medicine, Sendai 980

\begin{abstract}
Yaegashi, N., Yajima, H., Konno, R., Shikano, K., Sato, S. and Yajima, A. Detection of Human Papillomavirus Type $52 b$ in Cervical Dysplastic Tissue. Tohoku J. Exp. Med., 1989, 159 (3), 215-219—— We examined infection in the tissue of cervical dysplasia of human papillomavirus (HPV) $52 \mathrm{~b}$, which we recently isolated from cervical cancer. To screen a lot of samples, we used an assay system with an HPV DNA typing kit containing an HPV 33 probe that crosshybridizes with HPV 52b DNA. DNA samples from 123 patients with cervical dysplasia were first screened with this kit. Sixteen of these appeared to be positive, and they were subjected to Southern blot hybridization with the HPV 52b probe under highly stringent conditions. Of the 16 samples, two were found to have HPV 52b genome DNA. Our results, together with the fact that HPV 52b was isolated from cervical cancer, seem to support the notion that HPV $52 \mathrm{~b}$ infection is closely associated with the onset of cervical cancer. - human papillomavirus ; $52 \mathrm{~b}$; cervical dysplasia; southern blotting
\end{abstract}

The human papillomavirus (HPV) group, at present, is known to comprise more than 60 types, of which some have been implicated as pathogenic agents of sexually transmitted diseases, cervical carcinoma and its precancerous form, cervical dysplasia (Broker and Botchan 1986). We recently isolated a new type of HPV (HPV 52b) belonging to the genital pathogenic family of HPV from the cervical cancer tissue of a Japanese patient (Yajima et al. 1988). The genome DNA of HPV $52 \mathrm{~b}$ was found in three out of 15 specimens of cervical cancer and transformed NIH 3T3 in vitro in the same manner as HPV 16 DNA. Although these results suggest an etiological association between HPV 52b and cervical cancer, there have been no reports of the presence of HPV $52 \mathrm{~b}$ in cervical dysplastic tissue. In this study, we attempted to detect HPV 52b in the precancerous lesion, cervical dysplasia.

Received October 26, 1989; revision accepted for publication October 30, 1989.

*Present address : Department of Obstetrics and Gynecology, Yamagata Prefectural Central Hospital.

Reprints should be addressed: Akira Yajima, M.D., Department of Obstetrics and Gynecology, Tohoku University School of Medicine, 1-1 Seiryo-machi, Aoba-ku 980, Sendai, Japan. 


\section{Patients and Methods}

DNA samples from the cervical dysplasia tissue of 123 patients who were diagnosed as having cervical dysplasia and who were under observation at the Miyagi Cancer Society Center were screened with an HPV DNA typing kit (Vira Type ${ }^{\mathrm{TM}}$; Life Technologies, Gaithersburg, MD, USA). This kit's simple procedures make it very useful for the massscreening of HPV DNA. Cells were collected from the uterine cervix by scraping and stored in a tube at $-20^{\circ} \mathrm{C}$ until assayed. DNA was extracted, dot-blotted onto nylon membranes and hybridized with ${ }^{32} \mathrm{P}$-labeled standard probes included in the assay kit, according to the supplier's direction. Three mixed probes were included in the kit, i.e., HPV type 6 and 11, HPV type 16 and 18, and HPV type 31, 33 and 35. HPV 52b DNA was not included as a probe in this kit, but we have previously shown that HPV 52b DNA cross-hybridizes with that of HPV 33 (Yajima et al. 1988). Thus, it is possible that among patients positive for HPV 31/33/35 one patient's DNA might hybridize more strongly with HPV 52b than with HPV 33. To test this possibility, Southern blot hybridization was performed with biopsy specimens taken from HPV positive patients at the same time that cell samples for the kit assay were obtained. DNA was extracted from minced biopsy specimens by incubation in a solution containing $400 \mu \mathrm{g} / \mathrm{ml}$ of proteinase $\mathrm{K}$ (Boehringer Mannheim, Pentzberg, FRG) at $37^{\circ} \mathrm{C}$ for $12 \mathrm{hr}$ and extraction with phenol and chloroform. After it was dialyzed against $10 \mathrm{mM}$ Tris HCl buffer ( $\mathrm{pH}$ 7.5) containinbg $1 \mathrm{mM}$ EDTA, high molecular weight cellular DNA was digested with a mixture of RNase (Boehninger Mannheim, Pentzberg, FRG) and a restriction endonuclease, Pst I. Ten $\mu \mathrm{g}$ of digested DNA was separated by $0.6 \%$ agarose gel electrophoresis and blotted onto nitrocellulose filters. The filters were then baked and probed with an HPV 52b DNA probe labeled with ${ }^{32} \mathrm{P}$ by a random primed DNA labeling kit (Boehringer Mannheim), at $42^{\circ} \mathrm{C}$ overnight. The hybridized filters were washed with $0.2 \times$ standard saline citrate (SSC) and $0.1 \%$ sodium dodecyl sulfate (SDS) at $65^{\circ} \mathrm{C}$ and exposed to $\mathrm{x}$-ray films at $-80^{\circ} \mathrm{C}$ with intensifying screens.

\section{Results}

Examination with the kit showed 16 patients to be positive for HPV DNA. Of the 16 positive patients, seven were positive for types $16 / 18$, and nine for types $31 / 33 / 35$. No patients were positive for types $6 / 11$. Of 16 specimens that determined to be positive for HPV by the kit, two that were positive for HPV 31/ $33 / 35$ showed clear bands hybridized with the HPV 52b probe under highly stringent conditions by Southern blot analysis (Fig. 1). No hybridization with the HPV 33 probe was observed in any of 16 specimens under the same conditions, indicating that two of nine specimens positive for HPV 31/33/35 cross-hybridized with the HPV 33 probe under the indicated conditions of the kit assay system.

Histopathological examination of the HPV $52 \mathrm{~b}$ positive specimens (cases 1 and 2) disclosed mild dysplasia and severe dysplasia, respectively, and koilocytosis in both cases (Figs. 2 and 3). The Papanicolaou smears of these two cases were diagnosed as class IIIA and class IIID, respectively (Shikano et al. 1989). 


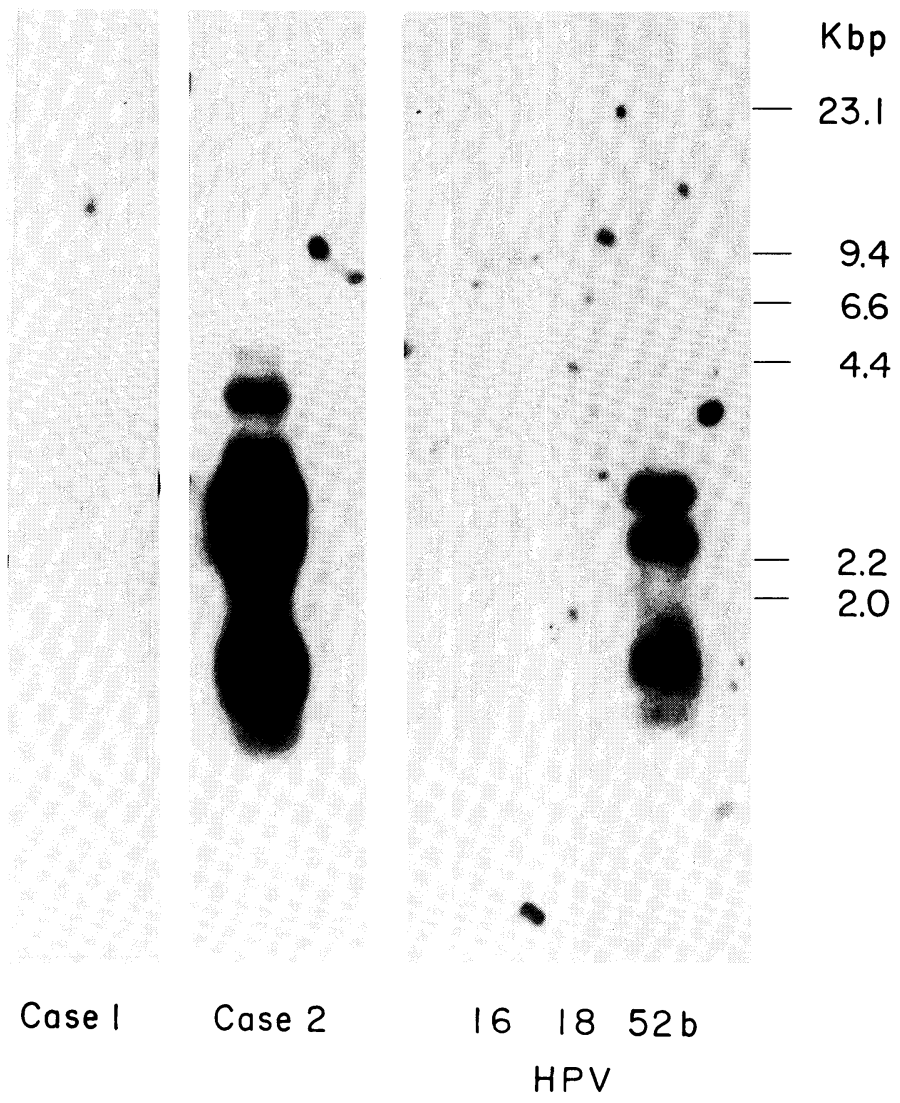

Fig. 1. Detection of HPV 52b DNA in the tissue of cervical dysplasia.

DNA was extracted from the tissue and cut with a restriction enzyme, Pst 1. Then, the DNA was electrophoresed and transfered onto nitrocellulose filters by Southern blotting. HPV 52b DNA labeled with ${ }^{32} \mathrm{P}$ was used as a probe. Hybridization was carried out under highly stringent condition. The DNA $(100 \mathrm{pg})$ of HPV types 16,18 and $52 \mathrm{~b}$, which was cut with Pst 1, was electrophoresed as a control. Lambda phage DNA digested with Hind 3 was used as a molecular weight marker. Signal detected with the case 1 specimens were very weak and may be visible only in the original photograph.

\section{Discussion}

HPV 52b was recently discovered in the tissues of cervical cancer in Japanese patients and was demonstrated to have the ability to transform culture cells in vitro, suggesting a causal relationship between HPV 52b infection and the onset of cervical cancer. To establish such a relationship, it is necessary to learn whether HPV 52b is present in the tissue of cervical dysplasia, since cervical dysplasia is considered to be a prodromic sign of cervical cancer. There have been no report, however, on the existence of HPV 52b in the tissue. Our result is the first evidence that HPV 52b exists in cervical dysplastic tissues and suggests 


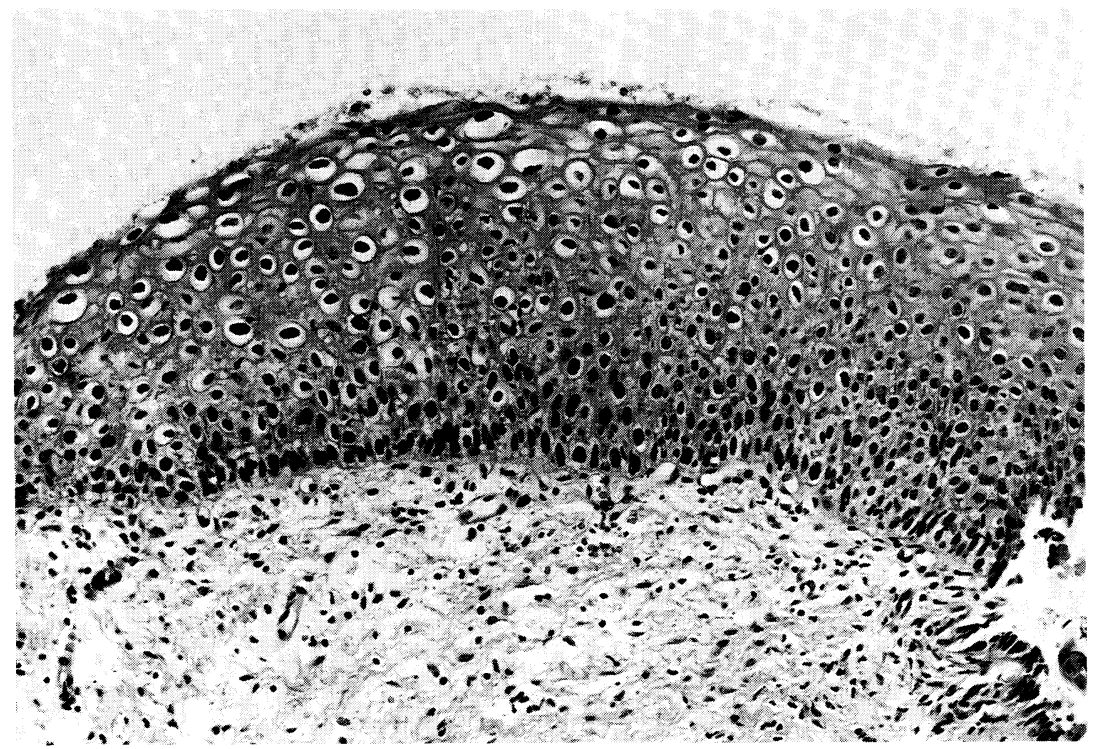

Fig. 2. Photomicrograph of case 1.

The specimens obtained by punch biopsy were stained with hematoxylin and eosin. Magnification, $\times 140$.

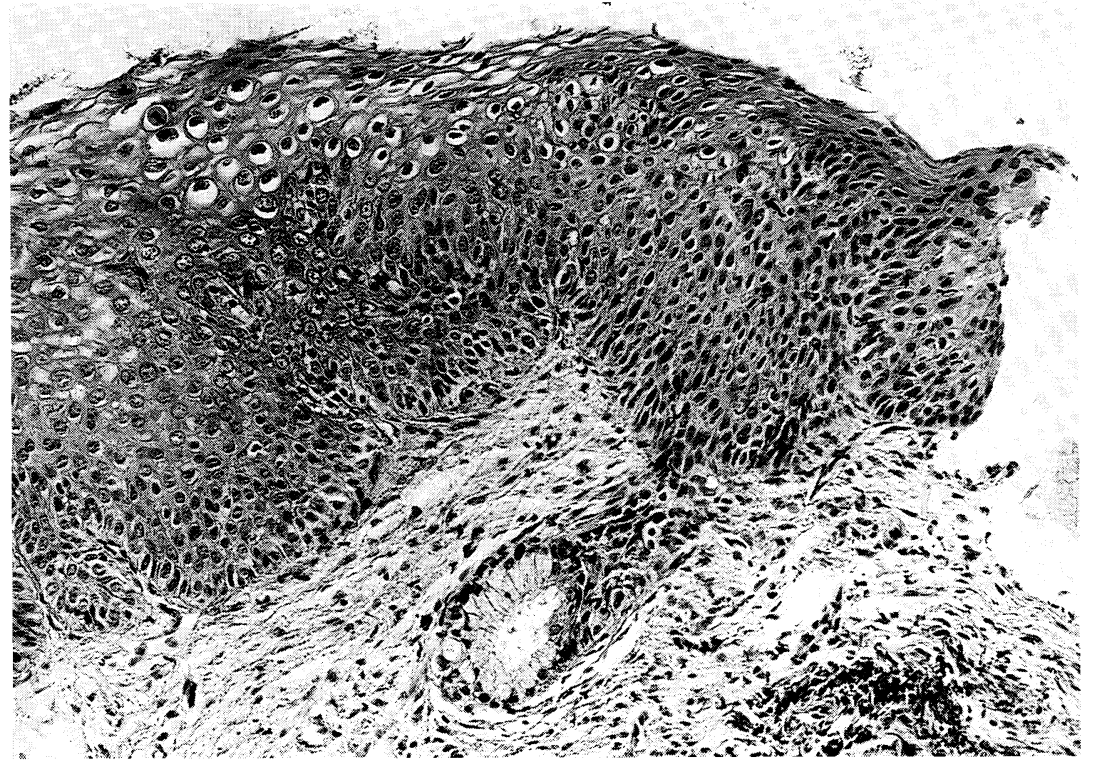

Fig. 3. Photomicrograph of case 2.

The specimens obtained by punch biopsy were stained with hematoxylin and eosin. Magnification, $\times 140$. 
the possibility that infection of cervical squamous epithelial cells with HPV 52b is involved in the in vivo onset of cervical cancer, as shown with HPV type 16 and type 18 (Zur Hausen 1986).

\section{Acknowledgments}

This work was supported in part by Grants-in-Aid for Cancer Research from the Ministry of Education, Science and Culture (Kawana-han) and from the Ministry of Health and Welfare for Comprehensive 10-Year Strategy for Cancer Control (Tenjin-han), Japan

\section{References}

1) Broker, T.R. \& Botchan, M. (1986) Papillomaviruses: Retrospectives and prospectives. In : Cancer Cells 4, edited by B.M. Steinberg, J.L. Bradsma \& L.B. Taichman, Cold Spring Harbor Laboratory, New York, pp. 17-36.

2) Shikano, K., Konno, K., Endo, A., Yajima, H., Chiba, H., Horiguchi, M., Sato, S., Yajima, A., Higashiiwai, H. \& Noda, K. (1989) Prevalence of human papillomavirus infection in cervical dysplasia by HPV DNA typing kit (Vira Type $\left.{ }^{\mathrm{TM}}\right)$. World Obstet. Gynecol., 41, 37-39. (Japanese)

3) Yajima, H., Noda, T., Villiers, E.M., Yajima, A., Yamamoto, K., Noda, K. \& Ito, Y. (1988) Isolation of a new type of human papillomavirus (HPV 52b) with a transforming activity from cervical cancer tissue. Cancer Res., 48, 7164-7172.

4) Zur Hausen, H. (1986) Papillomavirus in human urogenital cancer: Established results and prospects for the future. In: Viral etiology of cervical cancer, edited by R. Peto \& H. Zur Hausen, Cold Spring Harbor Laboratory, New York, pp. 327-332. 